Vol. 1, No. 2, December 2020: p. 95-110 DOI: 10.18326/islah.vl.i2.95-110

ISSN : 2723-407X

Website: $\underline{\text { https://e-journal.iainsalatiga.ac.id/index.php/islah }}$

\title{
Fundamentalism: Study of Islamic History
}

\author{
Djamiatul Islamiyah \\ IAIN Salatiga \\ d2017islamiyah@gmail.com
}

\author{
Submission Track: \\ Received: 20-09-2020 \\ Final Revision: 18-11-2020 \\ Available Online: 01-12-2020
}

\begin{abstract}
This paper is a literary study by analyzing various thoughts from various readings. The concern of this study is about fundamentalism in the study of Islamic history. The discussion material includes; contextualization, history, and various thoughts in response to fundamentalism. Regarding contextualization, a discussion arises whether fundamentalism exists as a product, as an agent, or both. If it is related to social changes in Islamic society in particular, is Islamic fundamentalism more of a religion matters? Some refer to the events of the Iranian revolution in 1979, to the 18th century Wahhabi movement, some others point to the Al-Mihnah policy by the Mu'tazilah during the reign of the caliph Al-Ma'mun in the 9th century. There are even those who say that the genealogy of fundamentalism has existed since the beginning of Islamic history, namely the emergence of the Khawarij which is seen as having the same qualifications as contemporary fundamentalism. Responses to fundamentalists have been written in various ways, such as the assumption about the hegemonic nature of Western civilization which is said to be an obstacle to the accommodation of the basics of mutual equality, as well as an attitude of mutual respect and recognition. Other responses were in the form of proposals for the deconstruction of fundamentalism, the idea of developing Islamic values of compassion and moderation as a way or policy of dealing with fundamentalism.
\end{abstract}

Keywords: Fundamentalism, Islamic History

\begin{abstract}
Abstrak
Tulisan ini merupakan studi literer dengan menganalisis berbagai pemikiran dari beragam bacaan. Concern studi ini adalah tentang fundamentalisme dalam telaah sejarah Islam. Materi pembahasannya meliputi; kontekstualisasi, sejarah, dan ragam pemikiran dalam merespon fundamentalisme. Tentang kontekstualisasi muncul diskusi apakah fundamentalisme eksis sebagai produk, sebagai agen, atau keduanya? Jika terkait perubahan sosial pada masyarakat Islam kususnya, apakah fundamentalisme Islam lebih merupakan religion matters? Dalam arti agama merupakan sebab dari fundamentalisme itu sendiri, atau lebih merupakan politicization of religion? Sementara berkaitan dengan sejarah fundamentalisme muncul pertanyaan "melalui" starting point mana harus "dibicarakan"?
\end{abstract}


Sebagian merujuk pada peristiwa revolusi Iran pada tahun 1979, pada gerakan wahabi abad 18, sebagian yang lain menunjuk pada kebijakan Al-Mihnah oleh Mu'tazilah pada masa pemerintahan khalifah Al-Ma'mun abad-9. Bahkan ada yang menyebut genealogi fundamentalisme sudah ada sejak awal sejarah Islam, yaitu munculnya Khawarij yang dipandang memiliki kualifikasi yang sama dengan fundamentalisme kontemporer. Respon terhadap fundamentalis pun ditulis secara beragam, seperti asumsi tentang sifat hegemonik dari peradaban Barat yang disebut menjadi hambatan bagi akomodasi dasar-dasar kesetaraan yang timbal balik, juga adanya sikap saling menghargai dan mengakui. Respon-respon lain berupa usulan untuk dekonstruksi fundamentalisme, ide menumbuh kembangkan nilai Islam tentang kasih sayang dan moderasi sebagai salah satu cara atau kebijakan menghadapi fundamentalisme.

Kata kunci: Fundamentalisme, Sejarah Islam

\section{INTRODUCTION}

The complexity of the phenomenon of what people call fundamentalism always attracts interest to become a topic of conversation in print media, social media and in scientific discussions. Although this discourse has ebbed and flowed along with certain "events" which in the public sphere are often addressed to Islamic fundamentalism we still remember the events of September 11 after the attacks in New York City and the Pentagon, almost everyone is aware of the existence of this movement. Not a few conferences and seminars were held inviting various practitioners of scientific disciplines such as: history, political psychology, religion, anthropology, human rights, and others. Not only that, conferences was also held involving many people with various religious and cultural backgrounds.

Various debates of opinion have arisen, from around the origins of the term fundamentalism and the proposed name that is more appropriate and capable of describing the religious movement. Names such as political Islam, Islamic extremism, Islamic Radicalism, ${ }^{1}$ Islamism, ${ }^{2}$ Integrism, ${ }^{3}$ or some even call it religious nationalism. ${ }^{4}$ Not to mention the problems related to the trigger or trigger for the emergence of the movement and the knick-knacks that colored the rolling history of its journey. Is fundamentalism as a

\footnotetext{
${ }^{1}$ G. Marranci, Understanding Muslim Identity: Rethinking Fundamentalism, (New York: Pub. Palgrave Macmillan, 2009), pp. 51

2 Bassam Tibi, Why They Can't be Democratic, Journal of Democracy, Vol 19 No 3 (2008), pp. 43

${ }^{3}$ Abdelwahab Meddeb, The Malady of Islam, Translated from French by Pierre Joris \& Ann Reid, (New York: Basic Books, 2002), pp. 226. In the book the author acknowledges the difference in intensity between fundamentalism and interism:coercion transform it's self into terorism, and struggle into war.

${ }^{4}$ Mark Juergens Meyer, The New Cold War: Religious Rationalism Confronts The secular Stage, (Barkeley: University of California Press, 1993), pp. 4.
} 
product or as an agent in the context of social change, is fundamentalism in essence more Islamic Politic or political Islam? Of course, each assumption has its own arguments according to its importance.

The next problem is in the historical context; from which starting point should fundamentalism be discussed? Some writers say that fundamentalism has emerged since the Iranian revolution in 1979, some others refer to the "Al-Mihnah" incident by mu'tazillah at the time of $\mathrm{Al}$ Ma'mun in the 9th century. ${ }^{5}$ There are even those who say that the characteristics of fundamentalism have existed since the beginning of history, namely related to the splinter movement which was later called the Khawarij movement after the 7 th century Siffin war. ${ }^{6}$

So familiar is the term Islamic fundamentalism with its actions that for most people, especially in the West, the word fundamentalism is automatically associated with Islamic fundamentalism, ${ }^{7}$ athough that assumption is rejected by some Islamic writers. Abdullah AnNaim, for example, states "the Islamic fundamentalism movement is not something new, nor is it permanently present in Islamic society. Fundamentalism is nothing more or less an indigenous spontaneous response to a profound political and social crisis". ${ }^{8}$ Likewise, Edward Said rejects the word fundamentalism which is automatically associated with Islam. According to Said, "the deliberately created associations between Islam and fundamentalism ensure that the average reader comes to see Islam and fundamentalism as essentially the same thing". 9

It must be admitted that there are two lines of thought related to the essence of Islamic fundamentalism. The first line of thought, which sees Islamic fundamentalism is not a manifestation of Islam as a teaching/religion, is represented by several of the writers mentioned above. The second line of thought sees Islamic fundamentalism, or what they

\footnotetext{
${ }^{5}$ Abdulwahab Meddeb, op.cit, pp. 17

${ }^{6}$ Ibid, pp. 237

${ }^{7}$ Gerri ter Haar and James J. Bussuttil (ed), The Freedom to Do God's Will, (London: Routledge, 2003), pp. 2

${ }^{8}$ Ibid

9 Ruud Koopmans, Religious Fundamentalism and Hostility againts Out-Groups: A Comparison of Muslim and Christian in Western Europe, Journal of Ethnic and Migration Studies, Routledge, Taylor \& Francis Group, Vol 41 No 1 (1015), pp. 36. The same criticism was also expressed by Bassam Tibi "that fundamentalism is a global phenomenon so it is not limited to the Islamic world" read Bassam Tibi, Ancama Fundamentalisme, Terj. Imran Rasyidi dkk. (Jogja: Tiara Wacana, 2000), pp. 25
} 
later call Islamic Extremism, ${ }^{10}$ is an Islamic product as a teaching and especially its religious text which is the Qur'an. For example, what Steve Bruce wrote was that fundamentalism was not a political opportunist who manipulated Islam as a religion but became inherent in its beliefs. ${ }^{11}$ Besides Bruce, Susan Rudolph wrote "although guided and sustained by the meaning system of transcendent realms, religion as practice is embodied in everyday life" 12 although Rudolph did not explicitly mention Islamic fundamentalism as a teaching, but from this citation it can be understood that religion is incarnate in everything people do in their daily life.

Whatever it is, differences of opinion are a natural thing in the academic world, especially when discussing fundamentalism which is so complex in context, that a uniform product in the form of thought is still difficult to achieve. This paper tries to discuss fundamentalism in Islamic history. The agenda of the problem includes; movement contextualization fundamentalism, fundamentalism in the trajectory of Islamic history, and responses to fundamentalism which are several alternative thoughts.

\section{FUNDAMENTALISM: CONTEXTUALIZATION OF MOVEMENT}

The general thesis concludes that religious fundamentalism occurs most frequently in times of social change. Meanwhile, according to Haar, "the term modernization is seen as fertile ground for the emergence of the fundamentalist movement. ${ }^{13}$ Maarif mentioned several theories that have discussed fundamentalism in the Islamic world, one of which and the most widely quoted is the failure of Muslims to face the current of modernity which is considered to be cornering Islam because of helplessness in facing the hot current, fundamentalists are looking for religious arguments to "entertain themselves" in an imagined world not yet polluted. ${ }^{14}$

10 This designation began to be directed towards Islamic fundamentalism after the September 11 incident. More details read G. Marannci, Understanding Muslim...., pp. 52

${ }^{11}$ G. Marranci, pp. 57

Regarding Bruce's opinion, Marranci notes that Bruce is not the only person who has made such a mistake, the main reason is that they have never lived together with Muslims, and have never held talks with Muslims from the community and the country. different. Read Marranci pp. 58

12 Paul Kingston, Contextualizing Islamic Fundamentalism: Review Article, International Journal Autumn, Association Professor of Political Saint Science, University of Toronto at Scarborough (1999), pp. 698

${ }^{13}$ Gerrie ter Haar, op.cit, pp. 2

${ }^{14}$ Abdurrahman Wahid, Ilusi Negara Islam, (Jakarta: The Wahid Institute, 2009), pp. 8 
Some writers understand Islamic fundamentalism as a historical linear process of alienation and frustration in facing secular ideology. ${ }^{15}$ While Gierycz ${ }^{16}$ concentrates in terms essential discussions on contributing factors to the development of religious fundamentalism, the literature on the subject points to the threat of modernity and is associated with secularization which is seen as deviating from traditional religious models and values. For example, the Ikhwanul Muslimin, as the first fundamentalist group, emerged as a reaction to the rapid westernization of Egypt as a result of British colonization. Therefore, it can be claimed that fundamentalism is one of the side effects of the secularization process.

Apart from resistance to secularism, Gellner ${ }^{17}$ views Islam as a religion showing several historical ideological elements conducive to fundamentalism. First, Islam is a scriptural belief that claims to be a perfect and final belief. Second, there is no room for a new prophet because Muslims view the prophet Muhammad as a closing prophet. Third, Islam does not have a priestly system and therefore there is no religious differentiation.

Still related to the contextualization of Islamic fundamentalism, according to Tibi, ${ }^{18}$ Islamic fundamentalism is a phenomenon that cannot be held in terms of traditional Islam or with references to Islamic territory itself. Although it describes itself as a challenge, in reality it is a cultural-defensive response to global issues. It cannot be understood if we fail to place it in the context of the modern global world in which it exists.

The various citation mentioned above give the impression that Islamic fundamentalism emerged as a product of social change, especially in the Islamic community. But as stated by An-Naim ${ }^{19}$ Islamic society is subject to the same principles relating to political and social life which are applied to other societies. Whether individually or collectively, Muslims try to fulfill basic needs such as food, shelter, security, political stability and so on like all other human beings. They also seek to work in such a way in the same or similar conditions that exist among all societies and communities, including the inevitable social change and adaptation in developmental responses that affect life

\footnotetext{
${ }^{15}$ G. Marranci, op.cit, pp. 55

${ }^{16}$ Michal Gierycz, Religion: A Source of Fundamentalism or a Safeguard Against It?, Religion, Vol 11 No 104 (2020), pp. 8

${ }^{17}$ G. Marranci, op.cit, pp. 54 $65-66$

${ }^{18}$ Bassam Tibi, Ancaman Fundamentalisme. Terj. Imran Rasyidi dkk., (Jogja: Tiara Wacana, 2000), pp.

${ }^{19}$ Gerrie ter Haar, op.cit, pp. 26
} 
individually and collectively. For the reasons mentioned above, fundamentalist movements should be seen as both products and agents of social change in Islamic societies and communities. These movements emerge as a result of certain configurations of factors and processes in each case, and seek to influence the course of events in the favor of their own social and political objectives. ${ }^{20}$

Then what is the real description of the experiences experienced by Muslims, especially those in the Middle East, regarding secularization? Milton Edward explains that secularism does not give Arabs and Muslims freedom, economic development, and democracy, but rather oppression, economic dependence on the West, and ferocious dictators supported by the Western democratic and secular state. ${ }^{21}$

If this is the case, then what are the ontological characteristics of fundamentalism? According to Razaghi, ${ }^{22}$ the intellectual foundation of fundamentalists lies in three ontological characteristics. First, they believe in an inerrant, natural, fundamental, and absolute existence. Second, that the scriptures and religious leaders are carriers of truth that cannot be debated. Third, they seek a single philosophy of life and avoid other peaceful ways of life.

According to Tibi, ${ }^{23}$ the collapse of communism in the East and the crisis of meaning that plagued the West have together opened the way for non-Western civilizations, especially Islam, to present their challenges to modernity and Western hegemony. In this case, Tibi, as written by Marranci, ${ }^{24}$ argues that Islamic fundamentalism is more than other fundamentalism. According to Tibi, fundamentalism is nothing more than the politicization of religion against Western values and modernism. However, for Tibi, Islamic fundamentalism is a special form of political ideology, stronger and more dangerous than other fundamentalism because Islamic fundamentalism is based on the manipulation of strong religious symbols.

\footnotetext{
${ }^{20}$ Ibid, pp. 25

${ }^{21}$ G. Marranci, Op.cit, pp. 67

${ }^{22}$ Mohammad Razaghi et.al, Religious Fundamentalism Individuality and Collective Identity: A Case Study of Two Student Organizations in Iran, Journals a Critical Research on Religion, Sage Pub, (2020): pp. 15

${ }^{23}$ Bassam Tibi, Ancaman Fundamentalime,(2000), op.cit, pp. 25

${ }^{24}$ G. Marranci, op.cit, pp. 56
} 


\section{FUNDAMENTALISM IN THE TRAJECTORY OF ISLAMIC HISTORY}

The use of the name fundamentalism is actually a debate among the community itself. This is because historically the term was used for the first time in the United States in the early 20th century. The name fundamentalism is given to the Protestant group who published 12 pamphlets (1910-1912) with the title The Fundamentals: A Testimony to The Truth. The fundamentalist community is arguing about the appropriateness of using the word fundamentalism because it is considered a product of the Western Christian experience, how possible that the term is then used to describe the various religious political movements in an Islamic society in a predictably diverse context. According to El-Fadl, the term fundamentalist is very inappropriate in the context of Islam because in Arabic the term is known as the word "Ushuli", which means someone who relies on basic and fundamental things. So the expression of Islamic fundamentalism raises an unavoidable misperception, that only fundamentalists base their interpretation on the Al-Qur'an and the Prophet's Sunnah, which are the basic and fundamental sources of Islamic theology and law. However, many liberal, moderate, progressive Muslims also describe themselves as ushuli or fundamentalists, without thinking that this will have a negative connotation. In an Islamic context it would be more appropriate to use the word puritan to describe a reductionist, fanatical and literalist view. ${ }^{25}$

However, as written by Haar, "the origin of the terms cannot prevent its application to the Islamic movement, Judaism, Hinduism, or other religious traditions, if they do find common salient features and important characteristics". ${ }^{26}$ The main key of the Protestant fundamentalism movement is its strict principles and militant opposition to the currents of modernism, liberalism, and biblical criticism, based on its literal and categorical beliefs. In this respect Islamic fundamentalism holds a fairly similar faith in relation to Islam and the Qur'an to justify the use of the term fundamentalism, in defining their movements. Furthermore, according to Haar, ${ }^{27}$ Islamic movements in North Africa and the Middle East use the Arabic term 'Ushuli' as an adjective and 'Ushuliyyah' as a noun (fundamentalist and fundamentalism). It is intended to portray themselves and their beliefs as part of a historical tradition dating back 10 centuries and not as a translation of an American term. Ushuliyyah

\footnotetext{
${ }^{25}$ Khaled Abdul E-Fadl, Selamatkan Islam dari Muslim Puritan, Terj. Helmi Mustofa, (Jakarta: PT. Serambi Ilmu Semesta, 2005), pp. 30

${ }^{26}$ Gerrie ter Haar, op.cit, pp. 28

${ }^{27}$ Ibid, pp. 28-29
} 
is an established term and appears in political discourse and Islamic theology as written in his book Asyari (D. 935) entitled Al Ibanah 'an Ushul Al-Diyanah. Other figures who emphasize the term ushuliyyah in their works are Al Ghozali (D. 1111), Ibn Taimiyah (D. 1328) and Abdul Wahab (D. 1787).

Furthermore, the use of the term fundamentalism according to Haar $^{28}$ began to be used since the Iranian revolution which was pioneered by Ayatullah Khomeini in 1979. At that time the word fundamentalism was used by journalists to describe the nature of the revolutionary process in Iran, and from there fundamentalism was used for other religious groups with intress. certain politics. For example in the weekly newspaper "Observer" 27 September 1981, Anthony Burgess wrote about the dangers of fundamentalism which Khomeini revived. This article received widespread attention and other comments which quickly began to link the word Islam with fundamentalist.

Islamic fundamentalists reject the idea of people's power or sovereignty except as an expression of God's will, as they understand it. For them, a simple means of implementing God's will is expressed in the Qur'an. ${ }^{29}$ The same thing was also stated by Tibi, ${ }^{30}$ "Islamic fundamentalism emphasizes the failure of the nation-state to be rooted in foreign civilization and Islamic fundamentalism which sees its opportunity as a political articulation of the crisis". This failure serves as an excuse to justify their de-legitimacy of the nation-state in the Islamic world. As an alternative to the nation-state they convey Islamic Nizzam.

Islamic legitimacy about the state has always been the cause of conflict and civil war since the death of the Prophet Muhammad (D. 632 AD). We still remember the debate about who has the most right to replace Rasullah between Sunni and Shi'i Muslims. For the Sunnis the first government (Abu Bakr) of the four caliphs in Medina was an ideal Islamic state and society. Meanwhile according to Shi'i the first three caliphs were considered invalid and had taken the position which was only for Ali (the grandson of the prophet who became the fourth caliph in Medina). In the Siffin war between Ali and Muawwiyah and other factions including some of Ali's supporters who were later referred to as Khawarij, they cursed all those who accepted the peace treaty in that war. ${ }^{31}$

\footnotetext{
${ }^{28}$ Ibid, pp. 3

${ }^{29}$ Ibid, pp. 29

${ }^{30}$ Bassam Tibi, Ancaman Fundamentalisme, pp. 13

${ }^{31}$ Gerrie ter Haar, op.cit, pp. 29
} 
The Khawarij group is said to be the oldest sect in Islam. They left Ali's ranks during the war with Muawiyah (Siffin War $657 \mathrm{M}$ ) because they did not agree with all the parties who had agreed to arbitration between the two caliphs (Muawiyah and Ali). This extremist sect with its high regard for fanaticism has a special facet of claiming kafir for anyone who disagrees with them. Khawarij also engaged in the politics of murder and terrorism. For that reason the Khawarij are often associated with contemporary fundamentalism. ${ }^{32}$ In other words, the first sect in Islam is considered to have the qualifications that exist in fundamentalism, or at least it can be called an embryo in Islamic fundamentalism.

In addition, Meddeb ${ }^{33}$ also argues that the genealogy of fundamentalism must include the events of the 9th century, namely the Al-Mihnah policy which was carried out during the caliph AL Ma'mun (786-833). The policy involved a literalist figure Ibn Hambal (780-circa 885) who was severely tortured for rejecting Mu'tazilah's thesis that the Qur'an was created by Allah (Hudus). This thesis rejects the dominant idea that was developing at that time that the Qur'an was not created but was qodim in nature. Ibn Hambal's resistance received resonance and acceptance among people who were eager to return to orthodox understanding of the Koran. Meanwhile, Mu'tazilah's ideas at that time became the official state ideology. Perhaps it is also for this reason that Haar wrote, "However, the intensity of demands for the application of sharia would rise usually in the form of a local or regional fundamentalist movement". 34

Sayyid Qutub (D. 1966) who is an ideologist from Ikhwanul Muslimin (The Muslim Brotherhood) said that nationality for Muslims is their religion. The movement emerged as a substitute for a nation-state that failed to establish an Arab identity. ${ }^{35}$ The same thing was stated by Razaghi ${ }^{36}$ that the emergence of Islamic fundamentalism and the formation of networks of fundamentalists was a reaction against the West which caused an identity crisis in Islamic society.

The Muslim Brotherhood movement which was initiated by Sayyid Qutub was the first wave of Islamism that occurred between 1967-1981. During this period jihadist ideas flourished. The second wave is the Shia movement which began with the Iranian revolution

\footnotetext{
${ }^{32}$ Abdulwahab Meddeb, op.cit, pp. 237

${ }^{33}$ Ibid, pp. 17

${ }^{34}$ Gerrie ter Harr, op.cit, pp.32

35 Asep Muhamad Iqbal \& Zulkifli, Islamic Fundamentalism, Nation-state and Global Citizenship: The Case of Hizbut-Tahrir, Indonesian Journal Of Islam and Muslim Societies, Vol 6 No 1 (2016), pp. 42

${ }^{36}$ Mohammad Razaghi, op.cit, pp. 2
} 
in 1979 and extended to 1980. Meanwhile, the third wave of Islamism emerged after the events of 11 September 2001 which had important differences in the objectives and scope of practice from the previous two waves. ${ }^{37}$ In this regard, according to Fadl, the history of fundamentalism or puritanism should be more precisely started from the 18th century Wahhabis. Even after the events of 11 September 2001 and the world waking up to the violence perpetrated by Al-Qaeda, the impact of the Wahhabis on modern Islamic thinkers is impossible to measure. ${ }^{38}$ History and conflicts in the Middle East have a central role in the discourse of Islamic fundamentalism, although there is no need to limit the so-called Islamic fundamentalism, radical Islam, political Islam, and jihadists as a consequence of the Middle East conflict. ${ }^{39}$

The tragedy of 11 September 2001 not only shook public awareness of the dangers of terrorism, but also changed the orientation and perception of the world about Islamic fundamentalism. While prior to the September 11 incident, the orientation of the study with this subject was intended to develop a comparative universal theory, but after the September 11 incident the study of fundamentalism was obscured by another phenomenon, namely terrorism. Not only that, while previously in this study Islamic fundamentalism was seen as resistance to 'modernization' and 'modernism', ${ }^{40}$ but after the September 11 tragedy scholars had to study readings about medieval theological thoughts, namely Ibn Taymiyah's thoughts. Islamic fundamentalism in this context is seen as a legacy of the past desire to impose a medieval theocracy system not only in Islamic countries but also in the West. One of Ibn Taimiyyah's famous books is Assyiyasah Syar'iyyah. According to Meddeb, "The radicalism emanating from such a book totally fulfills the expectations of the fundamentalists". ${ }^{41}$ In this book, Ibn Taimiyyah made jihad or holy war, as a main theme. According to Ibn Taimiyyah, jihad is as important as prayer and the teachings of other pillars of Islam such as shahada,

\footnotetext{
${ }^{37}$ Ibid, pp. 3
}

${ }^{38}$ Khaled Adbul El-Fadl, op.cit, pp 61

The foundation of Wahabi theology was built by Muhammad Ibn Abd Al Wahabi (D. 1792) which was later continued by Sayyid Qutub. In his teachings Abdul Wahab views that if there is someone who does not believe according to Abdul Wahab's standards then they are said to be kafirs and may be killed. Read pp. 65 . Therefore according to Fadl the traditional scholars used to describe the Wahhabis as the Islamic Khawarij in the modern era. Read pp.106

${ }^{39}$ G. Marranci, op.cit, pp. 76

${ }^{40}$ G. Marranci, op.cit. Pp. 76

${ }^{41}$ Abdulwahab Meddeb, op.cit, pp. 45 
fasting, zakat, and pilgrimage. To show the high status of jihad, he connected it with the image that jihad is a way to present religion. ${ }^{42}$

Apart from that, the September 11 incident has made several writers in their discussion of fundamentalism seek alternative terminology, especially for Islamic fundamentalism, namely "political Islam". According to Marranci, this term seems to emphasize its political orientation more than its religious and ritualistic aspects. ${ }^{43}$ Therefore Islam and its main text do not become a real source from which Islamic fundamentalism makes its ideological source, they use it more as a tool to find members and a moral shield for the actions of fundamentalists.

In connection with the political Islam terminology above, $\mathrm{Tibi}^{44}$ referred to the term "Islamism". According to Tibi, the term refers to political Islam, especially in the Arab world. In this section, Tibi views Islamism as a variety of religious fundamentalism. In his efforts to redefine security, the challenge of religious fundamentalism, not the challenge from Islam itself, is his concern. Islamism groups describe political Islam which in fact represents a security threat at the domestic, regional, and international levels.

The discussion about Islamism or political Islam leaves a long discussion about the essence of fundamentalism. The question is whether fundamentalism and its movement are what Bruce calls as "Religion Matters" or what Tibi calls as the politicization of religion. According to Steve Bruce, "Islam has a totalitarian view of culture and life, in which the religious matters and world domains cannot be divided without compromising one's faith". Therefore, "Religion is the cause of fundamentalism itself". ${ }^{45}$ Likewise, Gellner says "Islam as a religion shows some elements of its ideological history that are conducive to fundamentalism". ${ }^{46}$ Arjomand sees Islamic fundamentalism primarily as a political phenomenon even though he acknowledges Lawrence's opinion that the ideology behind the world view of fundamentalism comes from religious ideology. The description above shows that Gellner, Bruce and Arjomand have the same perspective that fundamentalism is a representation of religious teachings.

\footnotetext{
42 Ibid, pp. 48

${ }^{43}$ G. Marranci, Op.cit. pp. 63
}

44 Bassam Tibi, Between Islam and Islamism: A Dialogue With Islam as a Pattern of Conflict Resolution and Security Approach Vis-a Vis Islamism, in "Redefining Security in the Middle East", Tami Amanda Jaoby \& Brent E. Sasley (ed), Manchester University Press (2002), p.63

${ }^{45}$ Ibid, pp. 57

${ }^{46}$ Ibid, pp. 54 
Unlike all of the above opinions, Tibi differentiates between Islam and Islamism as political Islam. ${ }^{47}$ According to Tibi, "Fundamentalism is nothing than a politicization of religion against values and western modernism". 48

Another implication of the September 11 incident, on the one hand, has made experts who discuss Islamic fundamentalism more focused on Islam and violence. This is due to curiosity and an explanation of the reasons behind the September 11 incident. This topic has become the main term in several magazine articles and books, one of which is the writings of the Huttington Clash Civilization. But on the other hand, the September 11 incident has also made Islam a topic of study in security studies. This is what Tibi calls Western Islamophobia which has become more intense since the incident.

The various descriptions above conclude that the September 11 tragedy has very broad implications for Western perceptions of Islamic fundamentalism, about alternative terminology for Islamic fundamentalism, about the orientation of studies which then shifted to the topic of Islam and violence, and also the inclusion of Islamic topics as part of security studies because Islam is seen as a threat.

\section{RESPONSES TO FUNDAMENTALISM: SOME ALTERNATIVE THOUGHTS}

Toynbee in his famous book a Study of History suggests a historical mechanism in human civilization, namely challenge and response. ${ }^{49}$ So in this section the author wants to describe some responses in the form of thoughts related to the existence of religious fundamentalism including Islamic fundamentalism.

The September 11 incident, as written on the previous page, caused many interpretations, one of which was Huttington's thesis which interpreted the event as a clash of civilizations (between Islam and non-Islam). Huttington's thesis reaps pros and cons. AnNaim, for example, rejects this thesis on the grounds: first, this thesis is seen as imperialistic and hegemonic, and second, this thesis is seen as something that invites mutual enmity and destruction. ${ }^{50}$ While Tibi thinks that "Huttington has correctly pointed out the differences in the world view of people who come from different cultures and civilizations, Huttington views Tibi as failing to distinguish between Islam as a religion and Islamic fundamentalism

\footnotetext{
${ }^{47}$ Bassam Tibi, Between Islam..., pp. 62

${ }^{48}$ G. Marranci, op.cit. pp. 56

${ }^{49}$ Abdurrahman Wahid, Islamku Islam Anda Islam Kita, (Jakarta: The Wahid Institute, 2006), pp. 116

${ }^{50}$ Gerrie ter Haar, op.cit, pp. 44
} 
as an ideology". ${ }^{51}$ Marranci explained that Huttington's approach as well as other writers based their arguments on a monolithic understanding of Islam. Islam is depicted as leaving its adherents unable to enjoy modernization and leaving them in the dark medieval era. Therefore in order to understand tragic events like September 11 or otherwise, there is a need to go back to medieval interpretations and return to thoughts like Ibn Taymiyah.

Tibi in one of his writings quoted by Kingston ${ }^{52}$ argues that in order to avoid the clash of civilizations he hopes for accommodation on the principles of mutual equality, mutual respect, and recognition. This accommodation process would be difficult given the hegemonic nature of Western civilization. The roots of the rigid and sometimes violent doctrine of Islamic fundamentalism are found less in universalistic ideas and texts and they are more divided on the injustices, socio-economic, and political structures that are the product of the globalization process. ${ }^{53}$ Therefore, while fundamentalism can represent a danger to both domestic and international stability, the nature and causes of this danger, according to Kingston, needs to be better understood. First, fundamentalism is just one of many reactions in Islam about the dilemma of being a believer in facing the modern world, especially in the context of backwardness and political oppression. Second, the evidence is not strong enough to support Tibi's argument that fundamentalist anger is directed against civilization, especially the West. Another research stated that fundamentalist action is better understood as an event of competition between a variety of religious actors, especially from certain countries in Islam, assisted by connections with Muslim communities and organizations abroad. Third, when Islam begins to operate in more active and dynamic ways on states or at a transnational level, excessive attention is paid to the potential for producing its conflict, to the inaccessibility of equality and not to its profound contribution to improving global civil society and cooperation. ${ }^{54}$

Meanwhile, Bussuttil ${ }^{55}$ wrote about the importance of fundamentalism deconstruction as part of the policy response to religious fundamentalism. According to him, fundamentalism is not the domain of a belief, society, state, area, or level of economic and political development. Fundamentalism emerges as a reaction to changes in society.

\footnotetext{
${ }^{51}$ Bassam Tibi, Ancaman ..., op.cit, pp. 311

${ }^{52}$ Paul Kingston, op.cit, pp.697

${ }^{53}$ Ibid, pp. 701

${ }^{54}$ Ibid, pp. 701-702

${ }^{55}$ Gerrie ter Haar, op.cit, pp. 231

Regarding policy steps in dealing with religious fundamentalism, read the book in full pp. 230-237
} 
According to Bussuttil, "This key observation can be deconstructed in order to lay foundation for policies in response or anticipation".

Traditions that influence the reaction of fundamentalism may come from internal or external developments in society, such as pressures of modernization or globalization, threats to security, lack of resources including jobs, changes in political power or demographic shifts. This changing condition is seen by fundamentalism as a challenge to their religious values. They feel threatened, excluded, manipulated, or exploited. Then their reaction is to gather together on the basis of their religious interpretation. According to Bussuttil, $^{56}$ "in essence their problem and challenge is intelligence or at least the fundamentalists doubt the equality of those who do not follow their opinion". Therefore, policy actors can dissolve the intolerance inherent in religious fundamentalism in various ways as well as limit its potential influence. ${ }^{57}$

Tibi in her writings quoted by Kingston ${ }^{58}$ has recommendations about the importance of the West to promote democracy, human rights and the development of the Islamic world. Marranci $^{59}$ sees what is called Islamic fundamentalism not as something that exists in itself, but rather a certain process that is related to essential aspects of humanity, namely identity and self-identification. According to Tibi, ${ }^{60}$ Islam itself is basically a belief in a cultural and ethical system, and therefore it is not political in nature, but Islamism (Islamic politics) or Islamic fundamentalism is a political ideology even though one is based on religion. In the substantive-inclusive paradigm of Islamic political thought, in general according to Gus Dur, it is marked by the belief that Islam as a religion does not formulate theoretical concepts related to politics. According to this paradigm, the Qur'an as a holy book contains ethical aspects and moral guidelines for human life. That there is not a single verse from the $\mathrm{Al}$ Qur'an which emphasizes that Muslims must establish an Islamic state. ${ }^{61}$

An-Naim ${ }^{62}$ recommends an approach to the importance of understanding every movement of Islamic fundamentalism in its specific context to respect its main causes, internal and external dynamics, as well as possible transformations. In the current post-

\footnotetext{
${ }^{56}$ Ibid, pp. 232

${ }^{57}$ Ibid, pp. 54

${ }^{58}$ Paul Kingston, op.cit. Pp. 703

${ }^{59}$ G. Marranci, op.cit, pp. 77

${ }^{60}$ Bassam Tibi, Between Islam..., pp. 44

${ }^{61}$ Abdurrahman Wahid, Islamku Islam Anda ...., pp. xvii

${ }^{62}$ Gerrie ter Haar, op.cit, pp. 26-27
} 
colonial context, it is important to see Islamic fundamentalism as an expression of the Muslim community's right to self-defense, through the implementation of strong sharia, whether its application through the state or informal communal implementation in social relations and personal life-styles. From this perspective the issue is whether Islamic fundamentalism remains consistent with its representative claims of exclusion and Islamic identity, political system, and rule of law.

The management of religious fundamentalism in a liberal democracy is intended to protect human dignity and to promote peace, which will be a challenge for the years to come. To face this challenge a clear understanding of the core characteristics of fundamentalism is essential. ${ }^{63}$ El-Fadl firmly stated that if the two fundamental values in Islam, namely Islamic compassion and moderation, are remembered and developed in the hearts of Muslims, then extremism/fundamentalism will no longer have a place. ${ }^{64}$ Efforts to develop the value of Islamic compassion and moderation can certainly be done in various ways, one of which is through the design of educational curriculum materials from an early age, so that these two values become inherent in the person of every educational output.

\section{REFERENCES}

El-Fadl, Khaled Abdul. 2005. "Selamatkan Islam dari Muslim Puritan". Terj. Helmi Mustofa. Jakarta: PT. Serambi Ilmu Semesta.

Gierycz, Michal. 2020. "Religion: A or a Source of Fundamentalism Safeguard Against It?”. Journal Religions. Vol. 11, No. 104

Haar, Gerrie Ter, and James J. Bussuttil (ed). 2003. "The Freedom to do God's Will". London: Routledge.

Iqbal, Asep Muhamd, and Zulkifli. 2016. "Islamic Fundamentalism, Nation-state and Global Citizenship: The Case of Hizbut-Tahrir". Indonesian Journal Of Islam and Muslim Societies, Vol. 6, No. 1.

Kingston, Paul. 1999. "Contextualizing Islamic Fundamentalism: Review Article". International Journal Autumn. Association Professor of Political Saint Science, University of Toronto at Scarborough.

${ }^{63}$ Jakobus M. Vorster, perspective on The Core Characteritic of Religious Fundamentalism Today, Journal of The Study of Religious and Ideologies, Vol 7 No 21 (Winter 2008), pp. 57-58. In this book, Jakobus mentions seven main characteristics of religious fundamentalism

${ }^{64}$ Khaled Abdul El- Fadl, op.cit, pp. 347 
Koopmans, Ruud. 2015. "Religious Fundamentalism and Hostility againts Out-Groups: A Comparison of Muslim and Christian in Western Europe". Journal of Ethnic and Migration Studies. Routledge. Taylor \& Francis Group. Vol. 41, No. 1.

Maddeb, Abdelwahab. 2002. “The Malady of Islam”. Terj. Pierre Joris \& Ann Reid. New York: Basic Books.

Marranci, Gabriele. 2009. "Understanding Muslim Identity: Rethinking Fundamentalism". New York: Pub. Palgrave Macmillan.

Meyer, Mark Jurgens. 1993. "The New Cold War Religious Rationalism Confronts The secular Stage". Barkeley: University of California Press.

Razaghi, Mohammad et.al. 2020. "Religious Fundamentalism Individuality and Collective Identity: A Case Study of Two Student Organizations in Iran”. Journals a Critical Research on Religion. Sage Pub.

Tibi, Bassam. 2000. “Ancaman Fundamentalisme”. Terj. Imran Rasyidi et.al. Jogja: Tiara wacana.

Tibi, Bassam. 2002. "Between Islam and Islamism: A Dialogue with Islam as a Pattern of Conflict Resolution and Security Approach Vis-a Vis Islamism" in "Redefining Security in the Middle East, Tami Amanda Jaoby \& Brent E. Sasley (ed), Manchester University Press.

Tibi, Bassam. 2008. "Why They Can't be Democratic”. Journal of Democracy. Vol. 19, No. 3.

Wahid, Abdurrahman. 2006. "Islamku Islam Anda Islam Kita”. Jakarta: The Wahid Institute. Wahid, Abdurrahman. 2009. "Ilusi Negara Islam”. Jakarta: The Wahid Institute. 